VALUE CREATION: AN INTERNAL CUSTOMERS' PERSPECTIVE

AUTHORS: Debra Grace (Ph.D.)* Professor of Marketing

Department of Marketing, Griffith University Parklands Drive Southport Qld 4215

Australia

Phone: 617-55528027

Fax: 617-5552085

Email: d.grace@griffith.edu.au
Joseph Lo lacono

Phd Candidate

Department of Marketing,

Griffith University

Parklands Drive

Southport Qld 4215

Australia

Phone: 617-55528027

Fax: 617-5552085

Email: j.loiacono@griffith.edu.au

\footnotetext{
* Corresponding Author
} 


\title{
VALUE CREATION: AN INTERNAL CUSTOMERS' PERSPECTIVE
}

\begin{abstract}
Purpose: Practitioners and researchers have paid significant attention to understanding and delivering on the needs and wants of external customers. This being the case, we know quite a lot about one perspective of the value co-creation process (i.e. external customers' perception) but very little about other stakeholder perspectives, in particular, internal customers' perspectives of the value co-creation process.
\end{abstract}

Method: This paper draws on the works of Edvardsson et al. (2011), Giddens (1984), Sweeney and Soutar (200), Helkkula et al. (2012), Herzberg et al. (1959) and Wolf (1970) in order to build a conceptual model of value creation developed specifically from the internal customer's perspective.

Findings: The resultant conceptual model (shown in Figure 1) provides insight into the socio-structural and social exchange elements of the firm that provide the stimuli to value creation, which in the first instance, gratify (or not) the needs of internal customers and, secondly, influence the multi-dimensional value perceptions of internal customers.

Originality: The conceptual model of this paper provides a unique, pragmatic and useful framework for understanding how internal customers derive and perceive value within the social landscape of the firm. While empirical validation of the model is essential, the model, as presented herein, provides an excellent starting point for further investigation in this important, but largely under-researched, area.

INTRODUCTION 
Several academics (e.g., Gummesson 2008; Gyrd-Jones and Kornum, 2013; Lusch et al., 2007; Lusch and Vargo, 2014) have urged organizations to explore new means of creating and developing value for all stakeholders. For instance, Gummesson (2008) suggests all stakeholders have the right to have their needs and wants satisfied and later reiterates, "Involving customers is not enough. For a network to be productive, all stakeholders need to feel they get value in exchange" (Gummesson et al., 2014, p. 237). Furthermore, Lusch and Vargo (2014), in postulating the implications of S-D logic, argue that "co-created value suggests that the aim of the enterprise is not to produce and deliver value to customers, but rather to enable customers, and other stakeholders, to integrate resources and co-create value for themselves and others, based on individual needs and perceptions of value (p.189)." One important stakeholder group that has received very little research attention, in respect to the value co-creation process, is internal customers (i.e., employees of the firm).

Historically, marketers have concerned themselves with satisfying the needs and wants of external customers, with little regard being given to those of internal customers. This is surprising, given that, as early as 1994, Heskett et al. proposed the service profit chain, which clearly establishes the important link between the satisfaction of internal customers and the satisfaction of external customers. While several researchers (e.g., Judge et al., 2010; Seibert et al., 2011) have examined the antecedents of internal customer satisfaction, largely such investigations have focused on the fulfilment of economic needs such as pay level (Judge et al., 2010) and psychological needs like empowerment (Seibert et al., 2011). As a result, little insight into the value co-creation process involving internal customers has been gleaned. This represents a significant oversight; given the vital role internal customers play in the value co-creation process (Berry, 1995; Chung and Schneider, 2002; Koppitsch et al., 2013).

In addressing this important research gap, we take the view that internal customers are not only resource integrators but, importantly, are also key value beneficiaries within the value co-creation process. As such, while the conceptual model proposed in this paper maps out the value co-creation process involving firms and their internal customers, it does so from 
the internal beneficiary's perspective. In taking the view that value is created through the interpretation of and meaning derived from the value co-creation process (Ind and Coates, 2013), the key dependent variable in our model is internal customer perceived value (ICPV). ICPV is depicted as the outcome (i.e., the actual value that has been created from the internal customer's perspective) of the value co-creation process, which involves resource integration of the firm and internal customers. Thus, our conceptual model of internal customer perceived value (ICPV) identifies the dimensional nature of ICPV (see RQ1), establishes the key antecedents (i.e., value stimuli) to ICPV (see RQ2), and proposes other key influences (i.e., need gratification and temporal influences) in the value co-creation process (see RQ3). As a result, the literature is provided with a unique model that has the potential to prompt numerous research opportunities and which will provide significant "food for thought" for prudent practitioners.

\section{THEORETICAL BACKGROUND}

The seminal work of Vargo and Lusch (2004) has fundamentally changed the way we view the marketing exchange. While not denying the applicability of exchange as a central marketing construct, Vargo and Lusch (2004) challenged the traditional goods-dominant nature of exchange (i.e., goods being exchanged for money), in proposing a logic based on the notion of service being exchanged for service (i.e., S-D logic). In doing so, the S-D logic acknowledges the complexities of the marketing exchange by viewing "exchange in terms of value rather than products and networks rather than dyads" (Vargo and Lusch, 2008, p. 254). On this basis, value is co-created by all economic and social actors through the integration of operand and operant resources, giving rise to the notion of value-in-use (Vargo and Lusch, 2004). However, in recognizing that the term value-in-use subtlety resonates with a goods-dominant perspective, Vargo and Lusch (2008) suggested the term value-in-context was more appropriately aligned with S-D logic. This was proposed on the basis that, according to S-D logic, value is understood in the context of the beneficiary's reality.

Against this background, Edvardsson et al. (2011) applied the principles of social construction theories to extend our understanding of the service exchange and subsequent 
value co-creation process. In doing so, they argued that "service exchange and perceptions of value are embedded in social systems in which customers and companies have already established positions and roles" (p. 328). They further contend that the social context has a profound effect on the service exchange and value co-creation process, given that all resource integrators operate as part of a social context, implying its own unique set of norms and values. On this basis, Edvardsson et al. (2011) propose that value co-creation must be viewed from a social construction perspective and, as such, the term value-in-social context was coined. To further understand value from this perspective, it is important to identify and contrast the various actors that co-create value within the social context.

\section{Value Co-Creation: The Actors}

Recently, in reference to the metaphorical view of value co-creation (i.e., S-D logic), scholars have argued that the "the roles of both service providers and customers remain analytically unspecified, without a theoretically sound foundation for value and value co-creation" (Grönroos and Voima, 2013, p. 133). This argument challenges the view, espoused by current marketing terminology, that the firm holds the dominant position in value cocreation and concludes that the customer is the value creator and uniquely determines value through the experiential and contextual nature of the cumulative value co-creation process. In this view, the firm is fundamentally the facilitator of value for the customer, in that the firm offers value propositions and "has the opportunity to directly and actively influence its customers' value creation as well" (Grönroos and Voima, 2013, p. 145). Supporting the notion of "customers as value creators", it is important to understand this group not only from an external perspective, but also from an internal perspective. As such, we define internal customers as individuals who act on behalf of the firm, such as board members, executives, managers, and employees, and who directly benefit (through financial and socio-psychological value) from their contributions to the firm's value co-creation process.

While internal customers and external customers are often viewed from a polarized perspective, fundamentally the two groups share considerable common ground. First, internal and external customers are the "gatekeepers" of the operant resources in the value 
co-creation process (Lusch et al., 2007). In this sense, the firm (as the value space) provides the social structure within which internal and external customers deploy their operant resources. In other words, the firm's control over operant resources resides within the scope of its operand resources (socio-structural elements such as material resources, resources of authority, procedural rule, and moral rules) (Edvardsson et al., 2011) to provide access to and support its internal and external customers, as resource integrators.

Second, the value agendas of internal and external customers are fundamentally the same. For example, external customers apply their knowledge and skills (i.e., operant resources) to create value in the context of their own lives (Vargo et al., 2008). This activity is also true of the firm's employees (Vargo and Lusch, 2010). In fact, given that organizational life often consumes the personal lives of individuals (Lee et al., 2007), the notion of creating value in the context of their own lives may be more relevant to the firm's internal customers, than it is to its external customers. For example, external customers simultaneously co-create value with a conglomerate of firms as they go about their everyday lives. In most cases, one firm can easily be substituted with a multitude of others.

As internal customers are more contractually and temporally bound to one firm, the firm's internal value proposition has a profound effect, not only on internal customers' financial wellbeing, but also their social and psychological welfare. In other words, in line with the views of Vargo and Lusch (2011), we argue that internal customers are not only important value creators (i.e. resource integrators), but also important value beneficiaries in the value co-creation process. In fact, purpose, fulfillment, autonomy, satisfaction, close working relationships, learning (Chalofsky, 2003; Kohli et al., 1998; Mitroff and Denton, 1999), and "adding something to people's lives" (Bibby, 2001) are all benefits derived by internal customers from the value co-creation process, which have proven to be more salient than financial remuneration and job security. Therefore, the theoretical modeling of the firm's value proposition to external customers (e.g., Sandström et al., 2008) is equally, if not more, important in the context of its internal beneficiaries.

While internal and external customers strike fundamental similarities in terms of the resources they bring to the value co-creation table and their overarching value agendas, 
traditionally they have been viewed as "opposing" sides of the service exchange, with one group involved with the provision of service (i.e., internal customers) and one group involved with the consumption of service (i.e., external customers). The S-D logic opposes this view by promoting the reciprocal co-creation of value, "with each party bringing their own resource accessibility and integratibility into the process" (Vargo and Lusch, 2008, p. 257). However, the point of departure for the firm's internal and external customers is justified on the basis of proximity and interdependency associated with the firm's sociostructural elements. For example, the firm's internal customers "reside" within the firm's social structure (hence, the label "internal"), while external customers are positioned externally to the firm's social structure. This is not to say that external customers do not influence, or are not influenced by, the firm's social structure in the value co-creation process; they are just less entrenched in it. On the other hand, it is the social actions of the firm's internal customers that create and continually re-invent the firm's social structure. In this sense, the actions of internal customers dictate the firm's socio-structural elements, and the firm's socio-structural elements dictate the actions of internal customers. In other words, a much stronger cycle (characterized by proximity and interdependency) of sociostructural invention and re-invention exists for internal customers.

For internal customers, the firm's social structure represents a shared understanding, or social consensus, that shapes social perceptions and interactions of individuals (Deighton and Grayson, 1995). However, it is the degree to which the social consensus, and resultant social structure, supports the goals of the firm's individuals that will determine the efficacy of the value co-creation process. In other words, if a firm's social structure represents the social consensus of a minority (i.e., high power distance) it is more likely that individual behavior will deviate from the norm, thus thwarting the value co-creation process. Alternatively, if a firm practices servant-leadership, supporting open communication whereby "all information is shared and thus is symmetric" (Lusch et al., 2007, p. 15), then behavioral deviation from the norm is much less likely. As a result, there is a greater chance that individuals (i.e., internal customers) will effectively create value not only for the firm, but also for themselves. However, what we do not know is how the process of value cocreation (involving internal customers) is stimulated, occurs or is sustained. On this basis, 
the development of the conceptual model, described in this paper, is framed by the following research questions.

RQ1: What is the nature of perceived value for internal customers (ICPV)?

RQ2: What are the sources of value (i.e., value stimuli) in the value co-creation process, which impact ICPV?

RQ3: What relationships represent the dynamics between value stimuli and ICPV in the value co-creation process?

\section{PERCEIVED VALUE}

Contemporary thought promotes the idea that value derived from the service interaction is not only determined, but also controlled, by the external customer (e.g., Grönroos, 2011; Grönroos and Ravald, 2011; Heinonen et al., 2010; Helkkula et al., 2012; Grönroos and Voima, 2013). This notion links into historical schools of thought that have driven a great deal of research, which has examined how the needs and wants of external customers can be met. More specifically, significant attention has been given to the external customer's derivation and perception of value (e.g., emotional value, social value and functional value) (Payne et al., 2008; Sweeney and Soutar, 2001; Yi and Gong, 2012). Given our previous discussion relating to the resource and value agenda similarities of external and internal customers, we draw on the current external customer-focused perceived value literature to inform our investigation of internal customers' perception of value.

The theoretical models of Sweeney and Soutar (2001) and Helkkula et al. (2012) provide important frameworks upon which this investigation of internal customer value creation can proceed. Specifically, the multi-dimensional notion of perceived value, as being related to monetary, emotional, social and functional value assessments (Sweeney and Soutar, 2001), is also applicable to internal customers and provides a valid framework to describe various types of value assessments applicable to internal customers. In contrast, Helkkula et al.'s (2012) notion of "value in the experience" informs the current understanding of the nature of value co-creation specifically highlighting the perceptual, temporal and experiential (i.e., life-world) aspects of value co-creation that are also highly relevant in the context of 
internal customers. As such, these frameworks provide the theoretical underpinnings of the ensuing model development process.

\section{CONCEPTUAL DEVELOPMENT}

The notion of perceived value, as the key dependent variable in the value co-creation process of internal customers, is particularly relevant given that the very nature of value creation is perceptual and experiential (Helkkula et al., 2012). In other words, it is not a true reflection of reality that is sought (or even important for that matter). Rather, it is an understanding of how individuals perceive they experience value within their organization that is vital if greater appreciation and prediction of behavioral outcomes, associated with the value co-creation process, is sought.

\section{Internal Customer Perceived Value (ICPV)}

In conceptualizing the dimensionality (or types) of internal customer perceived value, the PERVAL model of Sweeney and Soutar (2001) provides a solid starting point. Using PERVAL as a theoretical foundation, the dimensions of internal customer perceived value are further conceptualized and defined. In doing so, the following dimensions are proposed: (1) monetary value (compensation), (2) functional value (task-related), (3) emotional value (intrinsic) and (4) social value (relational).

Monetary Value (Compensation): Sweeney and Soutar's (2001) first functional PERVAL dimension related to the value derived through the monetary exchange (i.e., value for money). From an external customer's perspective, this dimension referred to the customer's perceived value associated with the exchange of money for goods/services. From an internal perspective, money is exchanged for labor and, therefore, the value that internal customers perceive is associated with their evaluation of whether they are being paid what they believe they are worth. Thus, an assessment is made as to whether their salary package (i.e., salary, bonuses, incentives, other benefits of monetary value) fully compensates their labor efforts. The degree to which this occurs will determine the degree to which internal customers perceive they derive monetary value in co-creating value with the organization 
and its other stakeholders. On this basis, monetary value (compensation) is defined as the internal customer's perception of value derived from the salary package elements offered as compensation for participation in the value co-creation process.

Functional Value (Task-Related): Sweeney and Soutar's (2001) concept of functional value, relates to performance or quality of the goods/services in the marketing exchange. From an external perspective, this value dimension refers to the external customer's perception of value derived from the quality of product performance. From an internal perspective, this dimension relates to the value internal customers perceive from the functions (or tasks) they perform (i.e., their performance) in the employment exchange. In other words, if organizations support their internal customers to function (within their job roles) to the best of their potential, then the value derived through such labor support (or opportunity) could well manifest itself through a sense of accomplishment, personal development and potential for the internal customer to advance their career. Thus, functional value (taskrelated) is defined as the internal customer's perception of value derived from the firm's support/opportunity associated with effective task performance in the value co-creation process.

Emotional Value (Intrinsic Rewards): Sweeney and Soutar (2001) argued that customer perceived value also stems from the emotional benefits gained by using goods/services. For example, the enjoyment derived from having a massage, the fun and excitement associated with theme park usage, the tears shed when watching a sad movie all represent emotional responses to products. Similarly, internal customers also derive emotional value as they cocreate value with the firm and its stakeholders. For example, emotional responses to workrelated outcomes and relationships, such as pride, accomplishment, elation, anger, frustration and stress, are all common in the firm's internal environment. On this basis, emotional value is very relevant in this context. As such, from the internal customer's perspective, emotional value is defined as the internal customer's perception of value derived from the feelings or affective states aroused in the value co-creation process.

Social Value (Relationships): According to Sweeney and Soutar (2001), external customers derive social value via the social acceptance and approval associated with product usage. 
Thus, from an external perspective, this dimension is largely focused on the enhancement of customer self-concept. However, internal customers can also benefit from enhancement of self-concept, when working for organizations that have positive employer brand equity (Berthon et al., 2005). Nevertheless, from an internal perspective, the social dimension includes much more than self-concept enhancement as internal customers spend a great deal of time engaging in social exchange with the firm's internal and external stakeholders. On this basis, internal customers have the opportunity to derive many social benefits (i.e., from individual social exchanges) and relational benefits (i.e., from the development of relationships) over and above that related to the self-concept. For example, friendships are more likely to develop and provide "value" among internal customers (as opposed to external customers) given the close proximity (i.e., in terms of length of time and distance) of individual internal customers. Therefore, the concept of social value is of particular importance within the firm's internal realm. This being the case, social value is defined as the internal customer's perception of the value derived from the social and relational benefits generated in the value co-creation process.

On the basis of the preceding discussions, internal customer perceived value (ICPV) is defined as the total utility derived from the assessment of monetary value (compensation), functional value (task-related), emotional value (intrinsic rewards) and social value (relational). Therefore, a solid foundation upon which to develop the current investigation is laid. However, in order to understand the value co-creation process further, it is important to determine what aspects within the "value co-creation space" provide the sources of perceived value (value stimuli) for internal customers. Having a clear understanding of the value stimuli, influencing internal customers, enhances knowledge of the value co-creation process as a whole.

\section{Antecedents to ICPV: Value Stimuli}

The value-configuration space (or "value co-creation space") is assumed to be any domain in which various "actors" deploy their resources with the goal of co-creating value (Vargo and Lusch, 2004; Edvardsson et al., 2011). The firm represents the domain (or boundaries)

within which various actors (i.e., internal and external stakeholders) come together to 
exchange resources for the purpose of creating value for themselves and, subsequently, the firm. However, the firm does more than just provide a domain, or place, for value creation to occur between human actors. The firm provides the social structure, which impacts the value co-creation process of individuals and which is, reciprocally, impacted by the social actions of its human participants. This view is in line with the arguments of Edvardsson et al. (2011) who contend that "value-in-context should be understood as value-in-social-context" (p. 334). Thus, the socio-structural and the social exchange elements of the firm become a fundamental source of value for internal customers. As such, these frame the various forms of value stimuli depicted as antecedents to perceived value in the conceptual model.

Socio-Structural Elements: Structuration theory is used to explicate the firm's sociostructural elements (Giddens, 1984). According to Giddens (1984), the elements of social structure, which combine and determine social practice, include material resources, resources of authority, procedural rules, and moral rules (Giddens, 1984). These combine in various forms to determine structured practices (Giddens, 1984) and, in turn, structured practices are articulated through human conduct (social exchange elements) that continually maintain and reproduce the social structure. As such, the socio-structural elements of the firm represent the structural mechanisms that impact, and represent the value stimuli for, the value co-creation process of all participants. In particular, the ensuing discussions focus on the internal customer's relationship with the firm's socio-structural elements (i.e., material and authority resources; procedural and moral rules).

Material Resources refer to the allocation of resources among activities and members of society and provide the means for production (Giddens, 1984). The term "material resources" can be misleading as, from a social construction perspective, they include much more than what the firm owns (i.e., physical or financial assets), but rather how the firm allocates its resources in support of its members and its activities in order to create value. For example, the firm's resources are allocated, in part, to employee remuneration packages and employee support mechanisms (e.g., training programs, social clubs, etc.) with the goal of meeting the employee's resource needs. Similarly, the firm's resources are allocated to the development, production, and provision of goods and services that create value for its external customers. That being said, it is the appropriateness and effectiveness 
of resource allocation that provides a significant source of value for all stakeholders (both internal and external) and which ultimately impacts the value co-creation process as a whole.

Resources of Authority refer to how time and space are organized in terms of production and re-production, social mobility, legitimacy, and authority (Giddens, 1984). This sociostructural element essentially refers to the unequal distribution of resources, or the power structure of the organization articulated through the established formal chain of authority. The authoritative structure has considerable impact on the social practices of the firm's individuals, for example, in decision-making (Salancik and Pfeffer, 1974), perceived autonomy (Sadler-Smith et al., 2003), problem-solving (Cohen, 2008), negotiation (Olekains and Smith, 2013) and goal attainment (Webb and Sheeran, 2008). In other words, resources of authority can constrain or support the social actions and interactions of both internal and external customers, depending on how the chain of command is configured within the social structure of the firm. Consequently, the authoritative structure has a significant impact on the individual's ability and opportunity to deploy available resources toward value creation.

Procedural Rules define the practices and processes of the firm that guide the social actions of its human participants (Giddens, 1984). In this sense, the procedural rules of a firm impact the ability of individuals to create value within the firm. In other words, it is the degree to which these rules, often explicated in the firm's policies, assist or hinder the social actions and interactions of its individuals that will determine the extent to which value is cocreated for all parties (Ma and Dubé, 2011; Mentzer et al., 2001; Padgett and Mulvey, 2007). For example, since a firm's procedural rules guide the collective, their rigidity (or elasticity), in accommodating the resource integration (through social action and interaction) of its individuals, will ultimately determine the value individuals derive from acting within the social structure (i.e., the firm).

Moral Rules define which social actions are appropriate or permissible (Giddens, 1984). These rules often reflect values and set the standards for social action and interaction (Giddens, 1984). In contrast to procedural rules, moral rules are often implicit (unwritten) guidelines that dictate the manner in which individuals are expected to behave (Waters and 
Bird, 1987). The organizational literature demonstrates that moral rules are embedded in organizational culture; a multi-dimensional construct that represents a "set of shared mental assumptions that guide interpretation and action in organizations by defining appropriate behavior for various situations" (Ravasi and Schultz, 2006, p. 437). Like procedural rules, moral rules exist in collectivist terms as norms of the firm (Giddens, 1984). Therefore, the degree to which individuals become value beneficiaries within the firm depends on the reconciliation of their own "moral rules" with that of the firm. In other words, the derivation of value, through the integration of individuals' resources, hinges on their ability to perform within the firm's expected parameters of social actions and interactions (i.e., social exchange elements).

Social Exchange Elements: Social exchange theory, conceptualized by sociologist Homans (1958), views exchange as a negotiated process between parties (of at least two) that may result in economic or social benefit. This theory stems from a combination of economics, sociology and psychology and the nexus of this theory posits that human relationships are formed using a cost benefit analysis and an evaluation of alternatives (Emerson, 1976; Homans, 1958). Given that value is also viewed as a trade off between costs and rewards (Zeithaml, 1988), social exchange theory is appropriately applied in the context of this investigation of internal customer perceived value. As such, social exchange within and between internal and external stakeholder groups is further discussed.

Internal-internal stakeholder exchanges range, on a continuum, from discrete social interactions to continuous and developing workplace relationships that involve internal peers, supervisors and upper-level management. The organizational literature infers that internal customers are social agents (e.g., Masterson et al., 2000) of the firm as they act within the social structure of the firm, influencing the value co-creation process (Edvardsson et al., 2011). As such, workplace relations represent a significant source of value (i.e., value stimuli) for internal customers. For example, Cahill and Sias (1997) suggest that internal customers benefit significantly through co-worker support and kinship. In fact, in a study of workplace friendships, $60 \%$ of respondents (i.e., internal customers) reported pleasant colleagues as being more important to them than a good salary, with $74 \%$ of respondents having close relationships with colleagues (Randstad, 2012). On this basis, it is proposed that 
social exchanges, occurring within the internal environment of the firm, symbolize an important value source for internal customers.

Internal-external stakeholder exchanges, on the other hand, also provide an avenue for internal customers to derive value within the value co-creation process of the firm. Social exchange theory suggests that social interactions bring satisfaction when people receive fair returns for their expenditures (Cook and Emerson, 1987). Thus, as internal customers go about their everyday work-lives, negotiating with exchange partners such as external customers, suppliers, industry bodies and the like, they are subconsciously accessing the value stimuli. For example, emotional value results from satisfactory social interactions and social value results from social and relational benefits associated with internal-external stakeholder exchanges. In contrast, dissatisfaction and job stress erode perceived value (Beehr and Newman, 1978; Klassen and Chui, 2010) when unhealthy exchanges with external partners occur. Therefore, internal-external stakeholder exchanges exemplify relevant sources of value for this investigation in the context of internal customers.

In summary, the value stimuli in the value co-creation process of internal customers can be classified under two broad categories i.e., socio-structural elements and social exchange elements. As identified in the preceding sections, the firm's material and authoritative resources, along with its moral and procedural rules (i.e., socio-structural elements), provide significant scope for internal customers to source value within the value co-creation process. Similarly, social and relational benefits come via (or are sourced from) social exchange elements (within and between internal and external stakeholders), which also signify a worthy source of value for internal customers. Therefore, as shown in Figure 1, it is proposed that the socio-structural and social exchange elements associated with the employing firm provide the value stimuli upon which subsequent assessments of internal customer perceived value (i.e., monetary, functional, emotional and social) are made. However, we argue that the relationship between the value stimuli and perceived value is not a direct one; but rather it relies on the intervention of other key variables, referred to here as ICPV enablers.

\section{ICPV Enablers:}


In isolation, it is not possible to understand exactly how the value stimuli influence the perceived value of internal customers, given that the value stimuli (as shown in Figure 1) can only be thought of in descriptive terms. For example, firms' resources of authority (i.e., power structure) may be described as bureaucratic (i.e., vertical) with dictatorial chains of command or, alternatively, they may be described as open (i.e., horizontal) with collaborative chains of command, or the description may lie somewhere in between the two. However, for the current investigation, it is not important what the firm's power structure is, but rather how individuals (i.e., internal customers) respond to it. For example, one individual operating within a rigid vertical power structure, may find the inflexibility and dictatorial nature the firm's structure, as a significant source of stress, resulting in diminished perceived value. In this sense, the source of value (resource of authority) has a negative influence on perceived value. On the other hand, some individuals, who desire structure, direction and clarity, might thrive within that same power structure, thus, producing a positive effect on perceived value. On this basis, the impact of the value source on ICPV needs to be better understood, through establishing a "level playing field" that is not contaminated by individual differences.

Need Gratification (as conduit) ${ }^{1}$ : As previously discussed, individual needs have a significant influence in the service exchange and value co-creation process. Despite this, little is known about the role of internal customers' needs in creating value (e.g., Strandvik et al., 2012; Tuli et al., 2007). Thus, it is argued here that it is the gratification of needs that signifies a meaningful response to the value stimuli, which, in turn, ultimately influences the internal customer's assessment of value (i.e., perceived value). In recalling the previous example, regarding power structure, the first individual who experienced a negative response (i.e., stress) to the power structure did so because their individual needs were not being met. However, on the other hand, the second individual who thrived in that environment, was having his/her needs met. Thus, it can be said that there is a positive relationship between need gratification, derived from the value stimuli, and internal customer perceived value.

\footnotetext{
${ }^{1}$ We refer to need gratification as a conduit (not a mediator or moderator) as it is the need gratification, in the context of the value stimuli that influences ICPV. When future research attempts empirical validation of this model, value stimuli and need gratification will not be measured as separate constructs, it will be measured as need gratification associated with the value stimuli (one construct). This is graphically depicted in Figure 1.
} 
On this basis, need gratification becomes the conduit between value stimuli and perceived value.

Two early theories associated with need fulfillment, provide an appropriate foundation for understanding the gratification of needs (refer Figure 1) from an internal customer perspective i.e., Herzberg et al.'s (1959) two-factor theory and Wolf's (1970) need gratification theory. Over time, the two-factors of Herzberg et al.'s theory have been labeled in many different ways, from hygiene/motivator factors, intrinsic/extrinsic factors to context/content factors, and more. For comparative purposes, Wolf (1970) referred to the later (context/content factors) in his extension on this theory. While the two theories differ in the way in which context and content factors are viewed as affecting need gratification, both theories agree that measurable and direct consequences of need gratification include job satisfaction and job-related motivation. For example, context factors (e.g., company policy, administration, working conditions, interpersonal interaction etc.), which support behaviors that lead to the accomplishment of organizational objectives are argued to be more likely to influence (dis) satisfaction, whereas context factors (e.g., achievement, recognition, personal growth, social enhancement etc.) are more likely to influence jobrelated motivation (Herzberg et al., 1959).

Wolf (1970), on the other hand, concedes this may be the case in some, but not all, instances. He is more of the view that organizational factors (both context and content) either directly gratify needs or, alternatively, provide opportunity to gratify needs. Wolf (1970) goes on to argue that factors, directly gratifying needs, are linked to satisfaction/dissatisfaction, whereas factors, providing opportunity to gratify needs, stimulate job-related motivation. In the context of the present study, the value stimuli appearing in Figure 1 represent both context and content factors. Therefore, based on the theories of need gratification, it is these factors that serve to gratify or provide opportunity to gratify needs and, as a result, stimulate both job satisfaction and/or job-related motivation. This being the case, it is argued that need gratification (manifested as satisfaction and motivation), provides the conduit between value stimuli and perceived value. Thus, as shown in Figure 1, need gratification (i.e., satisfaction and motivation) is a 
necessary and salient inclusion in the modeling of internal customer perceived value. However, it is also important to consider potential moderators within the proposed model.

Temporal Influence (as moderator): The value literature suggests that temporal influences may play a significant moderating role in our conceptual model. The VALEX framework of Helkkula et al. (2012), articulates four propositions that reflects the experiential factors associated with value assessments. In the third VALEX proposition, the temporal nature of value is highlighted through the assertion that value in the experience is constructed on previous, current and imaginary future experiences (Helkkula et al., 2012, p. 61). Therefore, perceptions of value do not remain static but change (not necessarily systematically) at different points in time. Thus, to reiterate, the temporal nature of this proposition is highly relevant in the context of internal customers' perceived value as the concept of time is a defining characteristic of the nature of employment. Therefore, it is suggested that tenure (i.e., length of employment) and employment status (i.e., number of working hours per week) may signify strong moderating influences within the model. In other words, it is suggested that the relationship between the level of need gratification (stimulated by the value stimuli) and perceived value will fluctuate significantly on the basis of tenure and the employment status of the internal customer (refer Figure 1).

\section{CONCEPTUAL MODEL}

The final model, shown in Figure 1, represents the value co-creation process of internal customers that is built upon solid theoretical foundations drawn from the work Edvardsson et al. (2011), Giddens (1984), Sweeney and Soutar (2001), Helkkula et al. (2012), Herzberg et al. (1959) and Wolf (1970). In conceptualizing antecedents (or stimulants) to value cocreation, theories associated with the social structure of the firm (e.g., Edvardsson et al., 2010: Giddens, 1984) provided clarity in this respect, resulting in the proposal that a combination of socio-structural (i.e., material and authority resources, procedural and moral rules) and social-exchange (i.e., within and between internal and external stakeholders) elements represented the value stimuli at large. However, as shown in Figure 1, it is not the nature of the value stimuli elements that directly creates value, but rather it is the internal customer's response to the value stimuli, manifested as need gratification, that steers the 
model. The seminal theories of Herzberg et al. (1959) and Wolf (1970) are used to better understand need gratification, which leads to the proposal (as shown in Figure 1) that value will be created on the basis of the satisfaction and motivation (i.e., need gratification) derived from the value stimuli elements. Importantly, the model depicts the consequences of such need gratification as residing within the internal customers' perception of value and Sweeney and Soutar's PERVAL model provided an appropriate, adaptable framework for this investigation. As such, the model depicts internal customers' perceived value as a multidimensional construct comprising of four dimensions (i.e., monetary, functional, emotional and social value). Finally, it was Helkkula's et al. (2012) concept of "value in the experience" that helped us to complete the picture. Drawing on the VALEX model we identified temporal influences (i.e., tenure and employment status) as being potentially strong moderating contenders within the model.

\section{Figure 1: Value Creation: An Internal Customer Perspective}

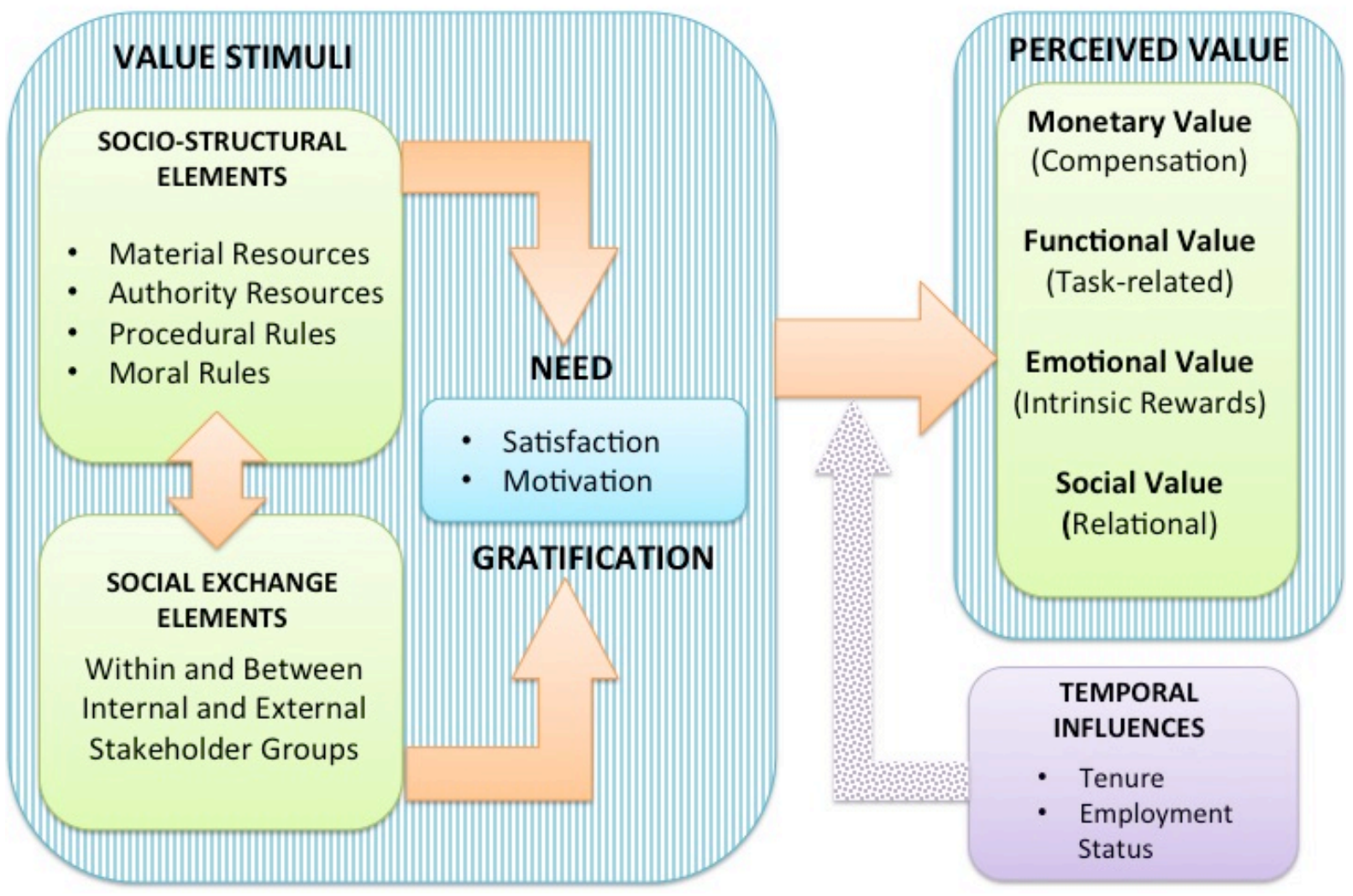

DISCUSSION 
We believe that the conceptual model of this paper (Figure 1) provides a significant starting point in understanding the value co-creation process that engages the participation of internal customers in creating value, i.e., from their perspective. In doing so, we identify internal customer perceived value (ICPV) to be multi-dimensional (i.e., monetary, functional, emotional and social) in nature, thus addressing RQ1. In addition, in accordance with RQ2, we identify the organization's socio-structural (i.e., resources and rules) and social exchange elements (i.e., within and between internal and external stakeholder groups) as providing the stimuli upon which internal customers' perceptions of value are initially derived.

Importantly, however, we argue that the link between value stimuli and value perceptions is dependent on two key influences, i.e. need gratification (i.e., satisfaction and motivations) and temporal influences (tenure and employment status), thus addressing RQ3. We acknowledge that there has been a plethora of HR research that has examined the various antecedents to job satisfaction and motivation. For example, research relating to job satisfaction and motivation has found key antecedents of both to be personality (Judge et al., 2002; Barrick et al., 2002), organizational culture (Lok and Crawford, 2001; Egan et al., 2004), person-organization fit (Silverthorne, 2004; Bright, 2007), work/family conflict (Bruck et al., 2002; Buelens and Van den Broeck, 2007), job autonomy (Abraham, 1998; Tyagi, 1985), job design (Morgeson and Humphrey, 2006; Hackman and Oldham, 1976), empowerment (Carless, 2004; Gagné et al., 1997), amongst others. However, it is important to discuss the difference between previous studies and our proposed model. Our model depicts the immediate reaction to value stimuli to be need gratification, which is expressed as the satisfactory and/or motivational response to the value stimuli. Therefore, the satisfaction/motivation we refer to is encounter-specific or, in other words, the immediate post-encounter evaluative judgment or "an effective reaction to the most recent transactional experience with the firm" (Garbarino and Johnson, 1999, p.71; Oliver, 1993). This type of satisfaction is very different to overall satisfaction. "Overall satisfaction, is a cumulative construct summing satisfaction with specific products and services of the organization and satisfaction with various facets of the firm" (Garbarino and Johnson, 1999, p. 71). The HR literature is replete with varying definitions of job satisfaction (Spector, 1997; Brief, 1998; Locke, 1976; Moorman, 1993, and more) and the operationalization of this construct often does not demonstrate face validity (Thompson and Phua, 2012; Brief 
and Weiss, 2002). For the most part, HR research reflects job satisfaction from a global perspective, with more task-specific job satisfaction research being criticized for its nongeneralizability (Pellegrini et al., 2010; Thompson, 2007; Robie et al., 1998). Our model, on the other hand, does not depict satisfaction and motivation to be job or task-related; but rather as being firm-related (i.e., as responses to the firm's socio-structural and social exchange elements). On this basis, what we are conceptualizing here is quite different from the ideas espoused in the HR literature. Furthermore, what is unique about the model is that it goes beyond the examination of individual emotional (i.e., satisfaction) and behavioral (i.e. motivation) reactions to firm provided social constructed stimuli (i.e., value stimuli), to understand the deeper evaluative responses of internal customers as they way up the benefits and sacrifices (i.e., perceived value) accrued as social actors within the firm. On this basis, the conceptual model of this paper makes a unique, significant and very worthy contribution to extant literature (e.g., marketing and HR).

\section{Practical Implications:}

In practical terms, the implications of this research are categorized as firm-level, job (task)level, and individual level.

Firm-Level: As managers manipulate marketing mix variables in order to satisfy the needs of their external customers, empirical validation of the conceptual model will provide insight into the strength of important antecedent variables that satisfy the needs of internal customers in the value co-creation process. At the firm level, It is expected that such findings will inform practitioners in relation to possible socio-structural elements that may be used to enhance value perceptions of employees and improve the health of value cocreation within the firm. Similarly, the findings are likely to inform practitioners regarding the interplay of social relationships within value co-creation, thus, providing them with potential for "social innovation" within the value co-creation process. For example, just as service innovation is pivotal in continually addressing the changing needs of external customers, social innovation (defined here as innovation associated with supporting, developing, and enhancing ideas, values, roles and relationships of organizations' stakeholder groups) may be equally important in gratifying the needs of internal customers. 
Furthermore, a validated scale measuring internal customer perceived value (ICPV) would enhance the current suite of marketing metrics, thus assisting practitioners' ability to measure, evaluate and monitor strategic initiatives and performance, pertaining specifically to their internal customer groups.

Job-Task Level: Practitioners might benefit from looking at task or job-related elements more laterally. For example, rather than concentrating solely on providing resources (i.e., tools and training) to develop and enhance task-related performance, managers should also consider developing and enhancing creativity within the value co-creation process. As spontaneity, play and exploration are all elements that are critical to creative thinking (Ind and Coates, 2013), the astute manager may consider incorporating these elements within the job designs of individuals. In order to do this, organizations must provide environments that are safe places that bring "the internal world of the imagination and the external world together" (ind and Coates, 2013, p. 90). Such environments must be characterized by trust; not just trust between the individual and the firm but also between individuals (Ind and Coates, 2013).

Individual Level: Finally, the model suggests that temporal influences will play an influential role in the value perceptions of internal customers. This presents an interesting dilemma for managers, not as easily dealt with as it is for external customers. Temporal influences in the relationship between firms and external customers have long been researched and documented. For example, the product life-cycle literature represents a vast knowledge base regarding consumers' relationships with firms/products/brand over the passing of time. Taking a similar line of inquiry in relation to internal customers and their firms would also provide useful information, particularly if a curvilinear pattern could determine crucial time factors in such relationships. However, any resultant strategies would be difficult to implement given that internal individuals are in the process of co-creating value with their firms at all different time stages i.e., some individuals may be new to the firm, whereas some other individuals may have been associated with the firm for 20 years, or more. Alternatively, some individuals may interact spasmodically with the firm (i.e., casual employees) whereas others are continually interacting with the firm (full-time tenured employees). Notwithstanding these challenges, it is imperative that managers begin to 
understand their internal customers and how the passing of time or amount of co-creation time influences their value perceptions.

\section{Future Research:}

The opportunities for future research lie within three key areas. Firstly, in drawing parallels with the PERVAL model (Sweeney and Soutar, 2001), the conceptual model (Figure 1) proposes that value perceptions of internal customer's can be classified into four broad dimensions (monetary, functional, emotional and social). However, empirical evidence must be collected to substantiate and/or augment the proposed dimensions. In doing so, the definitive boundaries of internal customer perceived value can be established and an appropriate multi-dimensional scale developed. Secondly, it is important to empirically test the relationships depicted in the conceptual model in order to validate its legitimacy. Finally, just as extensive research attention has been given to understanding the value creating behaviors of different market segments, future research should examine and compare the behaviors of internal market segments in the value creation process (i.e. across the structural model), thus providing evidence of the generalizability of the model. In closing, although Figure 1 depicts a framework that can support a multitude of research applications in the future, it will also facilitate future academic discussion and debate in this important area of knowledge enhancement.

\section{CONCLUSION}

In closing, the conceptual model of this paper provides a pragmatic and useful framework for understanding how internal customers derive and perceive value within the social landscape of the firm. Empirical validation of the model is essential and this may well lead to further enhancement of the model in the future. However, the model, shown in Figure 1, provides a great starting point for further research in this important area, which, to date, has largely been ignored. 


\section{REFERENCES}

Abraham, R. (1998), "Emotional dissonance in organizations: Antecedents, consequences, and moderators", Genetic, Social, and General Psychology Monographs, Vol. 124 No. 2, pp. 229-246.

Barrick, M.R., Stewart, G.L. and Piotrowski, M. (2002), "Personality and job performance: test of the mediating effects of motivation among sales representatives", Journal of Applied Psychology, Vol. 87 No. 1, pp. 43.

Beehr, T.A. and Newman, J.E. (1978), "Job stress, employee health, and organizational effectiveness: a facet analysis, model and literature review1", Personnel Psychology, Vol. 31 No. 4, pp. 665-699.

Berry, L.L. (1995), "Relationship marketing of services - growing interest, emerging perspectives", Journal of the Academy of Marketing Science, Vol. 23 No. 4, pp. 236245.

Berthon, P., Ewing, M. and Hah, L.L. (2005), "Captivating company: dimensions of attractiveness in employer branding", International Journal of Advertising, Vol. 24 No. 2, pp. 151-172.

Bibby, R.W. (2001), Canada's Teens: Today, Yesterday and Tomorrow, Toronto: Stoddart.

Brief, A.P. (1998), Attitudes In and Around Organizations, Sage, Utah.

Brief, A.P. and Weiss, H.M. (2002), "Organizational behavior: Affect in the workplace", Annual Review of Psychology, Vol. 53 No. 1, pp. 279-307.

Bright, L. (2007), "Does person-organization fit mediate the relationship between public service motivation and the job performance of public employees?", Review of Public Personnel Administration, Vol. 27 No. 4, pp. 361-379.

Bruck, C.S., Allen, T.D. and Spector, P.E. (2002), "The relation between work-family conflict and job satisfaction: A finer-grained analysis", Journal of Vocational Behavior, Vol. 60 No. 3, pp. 336-353.

Buelens, M. and Van den Broeck, H. (2007), "An analysis of differences in work motivation between public and private sector organizations", Public Administration Review, Vol. 67 No. 1, pp. 65-74. 
Cahill, D.J. and Sias, P.M. (1997), "The perceived social costs and importance of seeking emotional support in the workplace: gender differences and similarities", Communication Research Reports, Vol. 14 No. 2, pp. 231-240.

Carless, S.A. (2004), "Does psychological empowerment mediate the relationship between psychological climate and job satisfaction?", Journal of Business and Psychology, Vol. 18 No. 4, pp. 405-425.

Chalofsky, N. (2003), "An emerging construct of meaningful work", Human Resource Development International, Vol. 6 No. 1, pp. 69-83.

Chung, B.G. and Schneider, B. (2002), "Serving multiple masters: role conflict experienced by service employees", Journal of Services Marketing, Vol. 16 No. 1, pp. 70-87.

Cohen, A.J. (2008), "Negotiation, meet new governance: interest, skills and selves", Law \& Social Inquiry, Vol. 33 No. 2, pp. 501-562.

Cook, K.S. and Emerson, R.M. (1987), Social Exchange Theory, Sage Publications, Beverly Hills.

Deighton, J. and Grayson, K. (1995), "Marketing and seduction: building exchange relationships by managing social consensus", Journal of Consumer Research, Vol. 21 No. 4, pp. 660-676.

Edvardsson, B., Tronvoll, B. and Gruber, T. (2011), "Expanding understanding of service exchange and value co-creation: a social construction view", Journal of the Academy of Marketing Science, Vol. 39 No. 2, pp. 327-339.

Egan, T.M., Yang, B. and Bartlett, K.R. (2004), "The effects of organizational learning culture and job satisfaction on motivation to transfer learning and turnover intention", Human Resource Development Quarterly, Vol. 15 No. 3, pp. 279-301.

Emerson, R.M. (1976), Social exchange theory. Annual review of sociology, pp. 335-362.

Gagné, M., Senecal, C.B. and Koestner, R. (1997), "Proximal job characteristics, feelings of empowerment, and intrinsic motivation: a multidimensional model1", Journal of Applied Social Psychology, Vol. 27 No. 14, pp. 1222-1240.

Garbarino, E. and Johnson, M.S. (1999), "The different roles of satisfaction, trust, and commitment in customer relationships", Journal of Marketing, Vol. 63 No. 2 pp.7087. 
Giddens, A. (1984), The Constitution of Society: Outline of the Theory of Structuration, University of California Press, Berkeley.

Grönroos, C. (2011), "Value co-creation in service logic: a critical analysis", Marketing Theory, Vol. 11 No. 3, pp. 279-301.

Grönroos, C. and Ravald, A. (2011), "Service as business logic: implications for value creation and marketing", Journal of Service Management, Vol. 22 No. 1, pp. 5-22.

Grönroos, C. and Voima, P. (2013), "Critical service logic: making sense of value creation and co-creation", Journal of the Academy of Marketing Science, Vol. 41 No. 2, pp. 133150.

Gummesson, E. (2008), "Extending the service-dominant logic: from customer centricity to balanced centricity", Journal of the Academy of Marketing Science, Vol. 36 No. 1, pp. 15-17.

Gummesson, E., Kuusela, H. and Närvänen, E. (2014), "Reinventing marketing strategy by recasting supplier/customer roles", Journal of Service Management, Vol. 25 No. 2, pp. 228-240.

Gyrd-Jones, R.I. and Kornum, N. (2013), "Managing the co-created brand: value and cultural complementarity in online and offline multi-stakeholder ecosystems", Journal of Business Research, Vol. 66 No. 9, pp. 1484-1493.

Hackman, J.R. and Oldham, G.R. (1976), "Motivation through the design of work: test of a theory", Organizational behavior and human performance, Vol. 16 No. 2, pp.250279.

Heinonen, K., Strandvik, T., Mickelsson, K.J., Edvardsson, B., Sundström, E. and Andersson, P. (2010), "A customer-dominant logic of service", Journal of Service Management, Vol. 21 No. 4, pp. 531-548.

Helkkula, A., Kelleher, C. and Pihlström, M. (2012), "Characterizing value as an experience: implications for service researchers and managers", Journal of Service Research, Vol. 15, No. 1, pp. 59- 75.

Herzberg, F., Mausner, B. and Snyderman B. (1959), The motivation to work, Wiley, New York. 
Heskett, J., Jones, T.O., Loveman, G.W., Sasser W.E. and Schelsinger, L.A. (1994), "Putting the service profit chain to work", Harvard Business Review, (March-April), pp.164174.

Homans, G.C. (1958), "Social Behavior as Exchange", American Journal of Sociology, Vol. 63 No. 6, pp.597-606.

Ind, N. and Coates, N. (2013), "The meanings of co-creation", European Business Review, Vol. 25 No. 1, pp. 86-95.

Judge, T.A., Heller, D. and Mount, M.K. (2002), "Five-factor model of personality and job satisfaction: a meta-analysis", Journal of applied psychology Vol. 87 No. 3, pp. 530 606.

Judge, T.A., Piccolo, R.F., Podsakoff, N.P., Shaw, J.C. and Rich, B.L. (2010), "The relationship between pay and job satisfaction: a meta-analysis of the literature", Journal of Vocational Behavior, Vol. 77 No. 2, pp. 157-167.

Klassen, R.M. and Chiu, M.M. (2010), "Effects on teachers' self-efficacy and job satisfaction: teacher gender, years of experience, and job stress", Journal of Educational Psychology, Vol. 102 No. 3, p.741-756.

Kohli, A.K., Shervani, T.A. and Challagalla, G.N. (1998), "Learning and performance orientation of salespeople: the role of supervisors", Journal of Marketing Research, Vol. 35, No. 2, pp. 263-274.

Koppitsch, S., Folkes, V.S., MacInnis, D. and Porath, C. (2013), "The way a salesperson manages service providers influences customers' anger about problems", Journal of Personal Selling and Sales Management, Vol. 33 No. 1, pp. 67-78.

Lee, S., McCann, D. and Messenger, J.C. (2007), Working Time Around the World: Trends in Working Hours, Laws and Policies in a Global Comparative Perspective, Routledge, London and International Labour Organization, Geneva.

Locke, E.A. (1976), "The nature and causes of job satisfaction", Handbook of Industrial and Organizational Psychology, Vol. 1 No. 1, pp. 1297-1343.

Lok, P. and Crawford, J. (2001), "Antecedents of organizational commitment and the mediating role of job satisfaction", Journal of Managerial Psychology, Vol. 16 No. 8, pp. 594-613. 
Lusch, R.F. and Vargo, S.L. (2014), Service-Dominant Logic: Premises, Perspectives, Possibilities, Cambridge University Press, Cambridge.

Lusch, R.F., Vargo, S.L. and O'Brien, M. (2007), "Competing through service: insights from service-dominant logic", Journal of Retailing, Vol. 83 No. 1, pp. 5-18.

Ma, Z. and Dubé, L. (2011), "Process and outcome interdependency in frontline service encounters", Journal of Marketing, Vol. 75 No. 3, pp. 83-98.

Masterson, S.S., Lewis, K., Goldman, B.M. and Taylor, M.S. (2000), "Integrating justice and social exchange: the differing effects of fair procedures and treatment on work relationships", Academy of Management Journal, Vol. 43 No. 4, pp. 738-748.

Mentzer, J.T., Flint, D.J. and Hult, G.T.M. (2001), "Logistics service quality as a segment customized process", Journal of Marketing, Vol. 65 No. 4, pp. 82-104.

Mitroff, I.I. and Denton, E.A. (1999), "A study of spirituality in the workplace", Swan Management Review, Vol. 40 No. 4, pp. 83-92.

Moorman, R.H. (1993), "The influence of cognitive and affective based job satisfaction measures on the relationship between satisfaction and organizational citizenship behavior", Human Relations Vol. 46 No. 6, pp. 759-776.

Morgeson, F.P. and Humphrey, S.E. (2006), "The work design questionnaire (WDQ): developing and validating a comprehensive measure for assessing job design and the nature of work", Journal of Applied Psychology, Vol. 91 No. 6, pp. 1321-1339.

Olekains, M. and. Smith, P.L. (2013), “Dyadic power profiles: power-contingent strategies for value creation in negotiation", Human Communication, Vol. 39 No. 1, pp. 3-20.

Oliver, R. L. (1993), "Cognitive, affective, and attribute bases of the satisfaction response", Journal of Consumer Research, Vol. 20 No. 1, pp. 418-430.

Padgett, D. and Mulvey, M.S. (2007), "Differentiation via technology: strategic positioning of services following the introduction of disruptive technology", Journal of Retailing, Vol. 83 No. 4, pp. 375-391.

Payne, A.F., Storbacka, K. and Frow, P. (2008), "Managing the co-creation of value", Journal of the Academy of Marketing Science, Vol. 36 No. 1, pp. 83-96. 
Pellegrini, Ekin K., Scandura, T.A. and Jayaraman, V. (2010), "Cross-cultural generalizability of paternalistic leadership: an expansion of leader-member exchange theory", Group and Organization Management Vol. 35 No. 4, pp. 391-420.

Randstad (2012), "Employee Commitment and Personal Relationships in the Workplace", available at: http://www.randstad.com/press-room/research-reports (accessed 16 September 2013).

Ravasi, D. and Schultz, M. (2006), "Responding to organizational identity threats: exploring the role of organizational culture", Academy of Management Journal, Vol. 49 No. 3, pp. 433-458.

Robie, C., Ryan, A.M., Schmieder, R.A., Parra, L.F. and Smith, P.C. (1998), "The relation between job level and job satisfaction", Group and Organization Management, Vol. 23 No. 4, pp. 470-495.

Sadler-Smith, E., El-Kot, G. and Leat, M. (2003), "Differentiating work autonomy facets in a non-western context", Journal of Organizational Behavior, Vol. 24 No. 6, pp. 709731.

Salancik, G.R., and Pfeffer, J. (1974), "The bases and use of power in organizational decision making: the case of a university", Administrative Science Quarterly, Vol. 19 No. 4, pp. 453-473.

Sandström, S., Edvardsson, B., Kristensson, P. and Magnusson, P. (2008), "Value in use through service experience", Managing Service Quality, Vol. 18 No. 2, pp. 112-126.

Seibert, S.E., Wang, G. and Courtright, S.H. (2011), "Antecedents and consequences of psychological and team empowerment in organizations: a meta-analytic review", Journal of Applied Psychology, Vol. 96 No. 5, pp. 981 -1003.

Silverthorne, C. (2004), "The impact of organizational culture and person-organization fit on organizational commitment and job satisfaction in Taiwan", Leadership and Organization Development Journal, Vol. 25 No. 7, pp. 592-599.

Spector, P.E. (1997), Job satisfaction: Application, assessment, causes, and consequences. Sage publications, Thousand Oaks.

Strandvik, T., Holmlund, M. and Edvardsson, B. (2012), "Customer needing: a challenge for the seller offering", Journal of Business and Industrial Marketing, Vol. 27 No. 2, pp.132-141. 
Sweeney, J.C. and Soutar, G.N. (2001), "Consumer perceived value: the development of a multiple item scale", Journal of Retailing, Vol. 77 No. 2, pp. 203-220.

Thompson, E.R. (2007), "Development and validation of an internationally reliable shortform of the positive and negative affect schedule (PANAS)", Journal of Cross-Cultural Psychology Vol. 38 No. 2, pp. 227-242.

Thompson, E.R. and Phua, F.T. (2012), "A brief index of affective job satisfaction", Group and Organization Management, Vol. 37 No. 3, pp. 275-307.

Tuli, K.R., Kohli, A.K. and Bharadwaj, S.G. (2007), "Rethinking customer solutions: from product bundles to relational processes", Journal of Marketing, Vol. 71 No. 3, pp. 117.

Tyagi, P.K. (1985), "Relative importance of key job dimensions and leadership behaviors in motivating salesperson work performance", Journal of Marketing, Vol. 49 No. 3, pp. 76-86.

Vargo, S.L. and Lusch, R.F. (2004), "Evolving to a new dominant logic for marketing", Journal of Marketing, Vol. 68 No. 1, pp. 1-17.

Vargo, S.L. and Lusch, R.F. (2008), "From goods to service(s): divergences and convergences of logics", Industrial Marketing Management, Vol. 37 No. 3, pp. 254-259.

Vargo, S.L. and Lusch, R.F. (2010), "From repeat patronage to value co-creation in service ecosystems: a transcending conceptualization of relationship", Journal of Business Market Management, Vol. 4 No. 4, pp. 169-179.

Vargo, S.L. and Lusch, R.F. (2011), "Stepping aside and moving on: a rejoinder to a rejoinder", European Journal of Marketing, Vol. 45 No. 7/8, pp. 1319-1321.

Vargo, S.L., Maglio, P.P. and Akaka, M.A. (2008), "On value and value co-creation: a service systems and service logic perspective", European Management Journal, Vol. 26 No. 3, pp. 145-152.

Waters, J.A. and Bird, F. (1987), "The moral dimension of organizational culture", Journal of Business Ethics, Vol. 6 No. 1, pp. 15-22. 
Webb, T.L. and Sheeran, P. (2008), "Mechanisms of implementation intention effects: the role of goal intentions, self-efficacy, and accessibility of plan components", British Journal of Social Psychology, Vol. 47 No. 3, 373-395.

Wolf, M.G. (1970), "Need gratification theory: a theoretical reformulation of job satisfaction/dissatisfaction and job motivation", Journal of Applied Psychology, Vol. 54 No. 1, p. 87.

Yi, Y. and Gong, T. (2013), "Customer value co-creation behavior: Scale development and validation", Journal of Business Research, Vol. 66 No. 9, pp. 1279-1284.

Zeithaml, V.A. (1988), "Consumer perceptions of price, quality, and value: a means-end model and synthesis of evidence", Journal of Marketing, Vol. 52. No. 3, pp. 2-22. 